\title{
TRADITIONAL SILVICULTURE AND ITS OPPORTUNITY IN PRIVATELY OWNED FOREST MENOREH MOUNTAIN-KULONPROGO
}

\author{
Priyono Suryanto, San Afri Awang, Siti Muslimah Widyastuti, dan \\ Dwiko Budi Permadi \\ Faculty of Forestry Universitas Gadjah Mada \\ Email: psuryanto@ugm.ac.id
}

Dina Ruslanjari

Graduate School Universitas Gadjah Mada

\author{
Budi \\ Ministry of Forestry
}

\begin{abstract}
ABSTRAK
Sistem agroforestri terus berkembang mengikuti kebutuhan petani sehingga terjadi pergeseran imbangan ekologi dan ekonomi. Hal ini dapat dilihat dari silvikultur tradisional yang terus berkembang mengarah ke sistem monokulture dan input tinggi. Kondisi ini akan berakibat pada penurunan fungsi sistem agroforestri sebagai bentuk dari kelestarian. Penelitian bertujuan untuk mengetahui dinamika ruang, teknik silvikultur tradisional, dan pengetahuan yang berkembang dalam pengelolaan sistem agroforestri sebagai dasar menyusun pengelolaan yang lebih produktif dan berkelanjutan.Penelitian dilakukan di perbukitan menoreh, Kabupaten Kulon Progo, Yogyakarta dengan membagi menjadi 3 zona, yaitu dataran rendah (<300 mdpl), sedang (300-600 mdpl), dan tinggi ( $>600 \mathrm{mdpl})$. Pengambilan data dengan melakukan wawancara terhadap 46 informan kunci. Dokumentasi data meliputi pengetahuan lokal dalam praktek agroforestri, dinamika ruang dan manajemennya, silvikultur tradisional, dan orientasi pengelolaan agroforestri. Analisis dilakukan secara deskriptif yang terintegrasi melalui pendekatan diagnosis dan desain dalam agroforestri. Pengelolaan agroforestri baik di pekarangan dan tegalan berdasarkan model pemanfaatan ruangnya ada tiga strata, yaitu agroforestri awal, pertengahan, dan lanjut. Pada zona dataran rendah dicirikan dengan praktek agroforestriawal berbasis pada produksi pangan. Sedangkan di zona tengah dan atas lebih ke agroforestri pertengahan dan lanjut untuk produksi kayu dan jenis di bawah naungan dengan nilai ekonomi yang rendah, tetapi mempunyai diversitas yang tinggi. Silvikultur tradisional yang berkembang mengikuti pergeseran orientasi ke arah monokultur. Atas pertimbangan ini, maka diperlukan skema silvikultur yang adptif (SA) untuk manajemen agroforestri yang produktif dan berkelanjutan (SA-MAPB). Skema SA-MAPB-! Untuk menjaga agar agroforestri terus dapat memproduksi pangan dan turunannya sepanjang pengelolaan dengan tindak silvikultur pengaturan ruang dan berbagi sumberdaya yang intensif. Skema kedua SAMAPB-2 untuk pengelolaan agroforestri pertengahan dan lanjut yang produktif dengan pendekatan multilayer production melalui pengkayaan jenis yang intensif dan secara manajemen menggunakan pendekatan compatible management antar-unit lahan yang dimiliki oleh petani.
\end{abstract}

Kata Kunci: Agroforestri, Silvikultur, Adaptif, Perbukitan Menoreh. 


\title{
TRADITIONAL SILVICULTURE AND ITS OPPORTUNITY IN PRIVATELY OWNED FOREST MENOREH MONTAIN-KULONPROGO
}

\author{
Priyono Suryanto, San Afri Awang, Siti Muslimah Widyastuti, dan \\ Dwiko Budi Permadi \\ Faculty of Forestry Universitas Gadjah Mada \\ Email: psuryanto@ugm.ac.id
}

Dina Ruslanjari

Graduate School Universitas Gadjah Mada

\author{
Budi \\ Ministry of Forestry
}

\begin{abstract}
Agroforestry systems (AFS) are emerged to adapt with farmers needs, balancing economic and ecological conditions. In recent years, however, there has been shifting from ecology to economy, where traditional silviculture emphasizes toward more monoculture with high inputs. This condition will result in decreasing ecological function of AFS as one of the epitomes of sustainable. This research aims to know the role of traditional silviculture techniques practiced by farmers and to develop knowledge in AFS management as the basis to compose more productive and sustainable management. The study was conducted in Menoreh mountains, Yogyakarta. There zones based on altitude differences were distinguished, namely lowlands (<300 meter above sea level, masl), medium (300-600 masl) and high (> 600 masl). Data collecting was done by conducting deep interviews from 46 respondents, who were chosen randomly in each zone. The data included local knowledge practices, space dynamic and management, traditional silviculture, and orientation of AFS management. The analysis itself was done descriptively which was integrated through diagnosis approach and design in agroforestry systems. There are there models of AFS management based on there strata of space utilization both in homegarden and dry field, namely initial, intermediate and advanced agroforestry. In the lowland zone is initial agroforestry practicw, characterized by food production orientation. In the middle and upper zone are intermediate and advanced Based on this findings, aproductive and sustainable adaptive silviculture (AS) scheme for AFS management (AS AFS) is required, AS AFS_1 is oriented to keep agroforety being able to continualy produce food and its derivatis throughout the management. Intensive space arrangements and resources sharing silvicuculture measures are important instruments in this model. The second model, AS AFS_2 is for productive intermediate and advanced agroforestry with multilayer productions. It is suggested in this model to do intensive enrichment planting using tolerant species and compatible management approach of inter unit lands owned by farmers.
\end{abstract}

Keywords: Agroforestry, Silviculture, Adaptif, Menoreh Mountains. 


\section{INTRODUCTION}

Silvicultureisthe art and scienceof forest management (Nyland, 2006), especially in facilitating thedevelopment of the forestfromthe time when treesgrow and develop to harvesting stage. The silviculture development nowadays isnot only on the tree cultivation in forest areasbut also develops rapidly outside the forest. Trees out side forests cultivation develops in the world (FAO, 2007) including in Indonesia which has been developed with privately owned forests since 1951 by planting critical lands which owned by people (Mindawatiet al., 2006). The width of privately owned forests(POF) in Indonesia reached 1,272,505.61 hectares (MoF, 2006) and increased to 1,683,928.00 hectares in 2008 (MoF, 2009).

Many POF managements are done through agroforestry techniques either in the home garden or dry field (Suryanto et al., 2011; Suryanto et al., 2012a). Agroforestry silviculture is a series of silvicultural measures in agroforestry management which integrates the combination of timber products and seasonal plants in the same space and time (Suryantoet al., 2011). Privately owned forests which are composed of these agroforestry systems have functions to produce products which contain high nutrient (protein, vitamins, and minerals), herbs and spices, firewood, and occasionally fodder crops and timber (Kumar and Nair, 2004). The mandate of the POF based agroforestry that continues to develop from the timber to this ecosystem is increasingly apparent with the existence of global warming is a serious problem. Agroforestry plays an important role in mitigating climate changecarbon absorption capacity-which recently gets serious attention of the parties (IPCC, 2000; 2007).

The importance of privately owned forests in the life context above in its management is not free from challenges. The most important challenge is the shift of privately owned forests as a miniature forests to be monoculture forests. This shift occurred when privately owned forests as part of the field management by farmers, experience function strengtening as production advocate. This is because agricultural field has experienced production decrease due to the climate change. The increase of privately owned forests production is realized by the selection of fast growing species types with monoculture cropping systems. Thus, privately owned forest management has also been changed to follow the principles of land management system of high external inputs. On the basis of these considerations it is necessary to streng then silviculture technologies that are not only increase production but also conservation. This study aims to determine the space dynamics, traditional silvicultural techniques and knowledge developed in privately owned forest management as a basis for preparing more productive and sustainable management.

The study was conducted in six villages in the district Kulonprogo of Special Province of Yogyakarta, Java, Indonesia. Location determination with multistage sampling approach by dividing into the three regions based on altitude, then in every altitude area two villages were selected. From each village was later determined one district hamlet which was assessed by the Head of the Village which represent the village area in home garden and dry field management. The six villages research locations are: (1) Low areas (<300 masl) that are Giripeni and Bumirejo Villages, which are the villages in the lower altitude; (2) The medium altitude areas (300600 masl) Giripurwo and Hargotirto Village; (3) hilly areas (>600 masl) Purwosari and Jatimulyo Village.

Biophysical conditions in low areas are dominated by alluvial soil in Giripeni Village and Grumosol soil type in Bumirejo village. The types of soil in medium and hilly areas are more dominated by Lathosol soil type and Aluvial soil type in Hargotirto Village. Condition of low area slope is $<2^{\circ}$ and $3^{\circ}-15^{\circ}$, medium and hilly areas, its land conditions are mostly located in the slope of $16^{\circ}-40^{\circ}$ and $>40^{\circ}$. Lowest rainfall occurs 
or the driest month happens on July as the peak of the dry season, while the highest rainfall occurred in October, December, and May. The average monthly rainfall ranges between 170-190 mm/month. Average rain days throughout the study site range from 10-13 days of rain per month (CDPB Kulonprogo, 2011).

Data collection through interviews was conducted towards key informants. There are 46 key informants, consisting of farmers, community leaders, administrators of farmers group, and village agencies that have expertise and depth of knowledge on POF management conducted by the people in each village sites. Data analysis was conducted through descriptive analysis with diagnosis and design approaches for agroforestry (Raintree, 1986; Nair, 1993).

\section{DISCUSSION}

\section{Traditional Silviculture}

Privately owned forest (POF) managementin the Kulonprogo District on themiddleand upper zone shad similarity in the trend of land use development based on the ratio of the dominanceof trees andcrops. This blend has been developed by using agroforestry approach. Agroforestry model sare initial, intermediate, and advanced. Initial agroforestry dynamics would have trajectory which naturally towards intermediate agroforestry and advanced agroforestry (Figure 1).

\section{Traditional Approach}

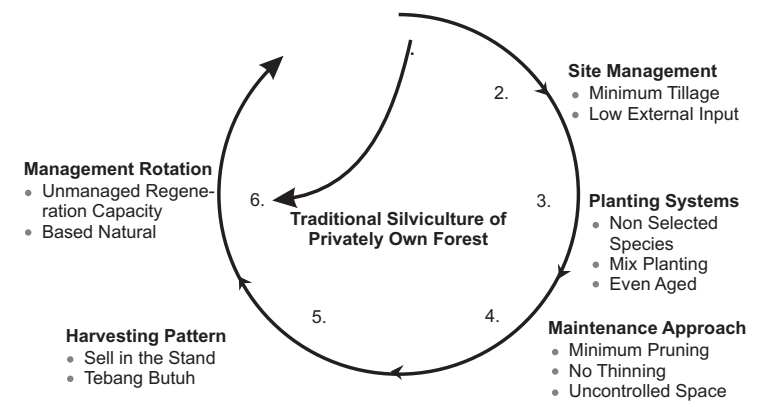

Figure 1: Traditional silviculture trajectories in POF management

In the context of the time dimension, agroforestry development in low landzone required longer time than in the middle and upper zones. This occuredbecause theorientation for higher food production in the lowlands. These conditions provid consequence that the development of a tree in the middle and upper zone more quickly than in the lower zone.

These intermediate and advanced agroforestries are usually characterized by areduced land ability to support cultivation ofseasonal crops, thus agroforestry is in fallow state. This fallow condition in agroforestrysystemsis typically caused by stress resource factors, namely sunlight. Never theless in this agroforestry condition there are alsoopportunities forfallow occurrence during the dry season or the presence of water stress factor.

Mean while the silviculture techniques developedin POF management which used traditional approach which is characterized with site management by applying minimalist land cultivation and low external input. Planting systems with silvicultural measuresdo not dospecies selection, planting with mixed model and produce POF stand swhich has age variation. The maintenance pattern applied namely very low pruning measure; thinning models, both commercial and non commercial have not yet existed as well as systematic space arrangements for trees optimal cultivation. Harvesting system practiced based on need and standingtrees selling within stands. Management for the nex trotation relies on natural regeneration, yet regeneration capacity management in POF management has not yet developed.

\section{Local Knowledge Practicein POF}

Developed local knowledge in Kulonprogo District in POF management can be explained that between the knowledge developed in the middle and upper zones have similarities. While the one developed in lowland zone has different characteristics with them. In the middle and upper zones, types and site integration was affected by the type of developed culture with many types developed and with not much consideration on market demands. This knowledge also sug- 
gests that the integrity and POF biophysical dependence are closer to the culture.

This is different from the low land zones that in developing POF show that type commodity selection integration with the site are highly determined by market orientation. These conditions provide a consequence thatPOF system with the presence of type domi- nance or low diversity values if it is compared to the othertwo zones. It also provides knowledge about yield harvesting regularity which is more regular and its organization in role sharing is clearer. Thus POF knowledge in the low landzone has stronger integrity, biophysical closeness, and dependen ceto market than in the twoo ther zones.

Table 1

Local knowledge practices in POF management in Kulonprogo District

\begin{tabular}{l|l|l|l|l}
\hline \multirow{2}{*}{ No } & \multirow{2}{*}{ Component } & \multicolumn{3}{|c}{ Privately Owned Forests system } \\
\cline { 3 - 5 } & Integration & $\begin{array}{l}\text { Biophysics and } \\
\text { market integration }\end{array}$ & $\begin{array}{l}\text { Biophysics and culture start } \\
\text { integrating with market }\end{array}$ & $\begin{array}{l}\text { Biophysics and culture start } \\
\text { integrating with market }\end{array}$ \\
\hline 2. & Regularity & $\begin{array}{l}\text { Seasonal crop yield } \\
\text { harvesting }\end{array}$ & $\begin{array}{l}\text { Irregular harvesting as } \\
\text { part of economy unit }\end{array}$ & $\begin{array}{l}\text { Irregular harvesting as part } \\
\text { of economy unit }\end{array}$ \\
\hline 3. & Unity & $\begin{array}{l}\text { Field unit and } \\
\text { production unity }\end{array}$ & $\begin{array}{l}\text { Field and culture unity } \\
\text { starts as production unit }\end{array}$ & $\begin{array}{l}\text { Field and culture unity } \\
\text { starts as production unit }\end{array}$ \\
\hline 4. & Organization & $\begin{array}{l}\text { Role sharing } \\
\text { withing field unit }\end{array}$ & $\begin{array}{l}\text { Family members role } \\
\text { sharing gets stronger } \\
\text { from economy unit }\end{array}$ & $\begin{array}{l}\text { Family members role } \\
\text { sharing gets stronger from } \\
\text { economy unit }\end{array}$ \\
\hline 5. & $\begin{array}{l}\text { Inter } \\
\text { components } \\
\text { closeness }\end{array}$ & $\begin{array}{l}\text { Crops yield com- } \\
\text { ponents are close to } \\
\text { Market demand }\end{array}$ & $\begin{array}{l}\text { Crops yield components } \\
\text { start being close to } \\
\text { market demand }\end{array}$ & $\begin{array}{l}\text { Crops yield components } \\
\text { start being close to market } \\
\text { demand }\end{array}$ \\
\hline 6. & $\begin{array}{l}\text { Inter } \\
\text { components } \\
\text { connectivity }\end{array}$ & $\begin{array}{l}\text { Yield components } \\
\text { related to mainte- } \\
\text { nance and types of } \\
\text { crops }\end{array}$ & $\begin{array}{l}\text { Production components } \\
\text { start relating to } \\
\text { biophysical and culture } \\
\text { components }\end{array}$ & $\begin{array}{l}\text { Production components } \\
\text { start relating to biophysical } \\
\text { and culture components }\end{array}$ \\
\hline 7. & $\begin{array}{l}\text { Each other } \\
\text { inter- } \\
\text { dependence }\end{array}$ & $\begin{array}{l}\text { Farmers family } \\
\text { dependence towards } \\
\text { crop yield buyers } \\
\text { and vice versa }\end{array}$ & $\begin{array}{l}\text { Farmers family start } \\
\text { having dependence to } \\
\text { market and vice versa } \\
\text { on crops/trees yield }\end{array}$ & $\begin{array}{l}\text { Farmers family start having } \\
\text { dependence to market and } \\
\text { vice versa on crops/trees } \\
\text { yield }\end{array}$ \\
\hline
\end{tabular}

\section{Adaptive Silviculture in POF}

In general, POF management in Kulonprogo District based on space dynamics of agroforestry systems showed that ecological - social - economical shift balance occurred towards economy orientation through production increase by shortening the crop rotation. This shift is evident from the rearrangement of POF constituent types by planting species that are fast growing with monoculture system thus products harvesting is faster. However, these conditions resulted in POF management which has low product diversity trend due to monoculture. This does not only occur in the home garden land unit but also in dry field land unit.

This shift will result an imbalance in POF sustainable management. In the effort to build consistent POF as the epitome of sustainability thus it is a necessary to conduct constructive steps through adaptive silviculture (AS). This technology does not only prevent the acceleration of community based POF management orientastion leaving ecological and cultural aspects but being a winwin solution to balance these aspects.

Adaptive silviculture developed harmonizes space arrangement measures and 
resources sharing with compatible management so that becomes more productive through the multilayer production. Thus, POF management developed is friendly with technology and prospective management unit. This kind of POF management needs to be supported by strengthening the business unit making it more productive and sustainable.

Adaptivesilvi culture in managing productive and sustainable POF has two trajectories, namely first, to maintain food production sustainability without leaving ecological values. This trajectory is for POF management with maintaining agroforestry systems that are always in initial and intermediate level. Mean while, the technology used is by applying space arrangement approach by integrating intensive pruning, thinning, and harvest- ing based on needs. This approach combined with sharing resource sthrough root pruning and nurse trees species for streng thening safety nets and nutrients pumping (Figure 2).

Second trajectory is to encourage POF management by activating intermediate and advanced agroforestry to avoid unproductive fallow. This trajectory integrates compatible management with multilayer production. Compatible management uses land unit management approach as a whole namely to synergize home garden and dry field units. This approach combined with multilayer production scheme by conducting enrichment planting for fruit plants, multi-purposes trees species, fast growing species, slow growing species and potential herbal planting which is shade resistant. This trajectory is to encourage more productive and sustainable POF management (Figure 2).

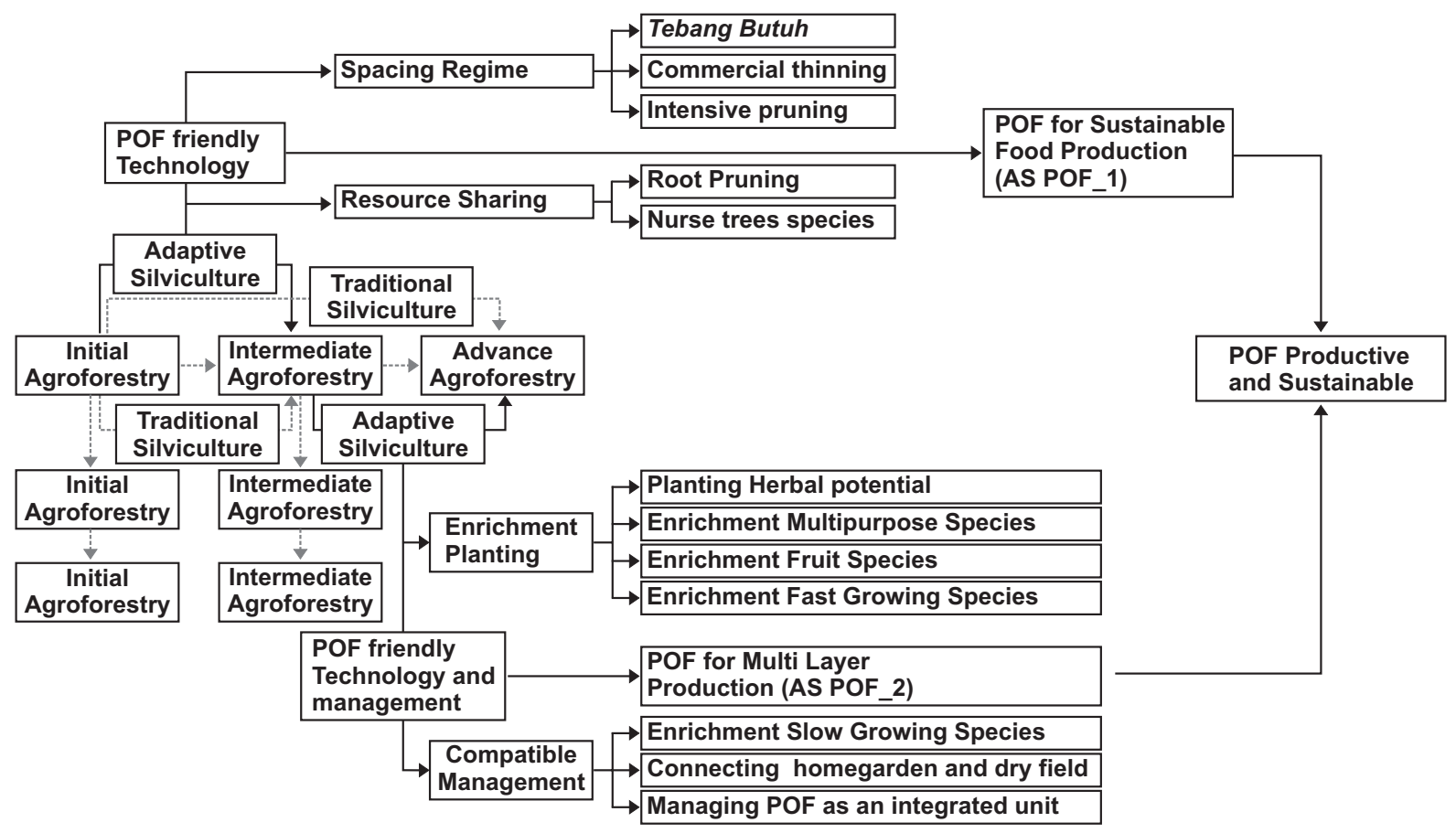

Figure 2. POF management based on Adaptive Silviculture

POF management in Kulonprogo District is strongly influenced by space dynamics of both verticaland horizontal space that is used for tree and annual crops cultivation. The high diversity of plant species in these home gardens and the mix ture of annual sand perennial sat different heights result in acomplex horizontal and vertical structure (Abdoellahetal., 2006). The presence of trees and crop sinthe same space and time hascomplex interactions in resources use, both in the soiland above ground. Trees in a groforestry systems strongly compete with cropsfor light, resources, shade and water, and thus 
can have a devastating effecton cropyields (Barrios, 2003).

The development of agroforestry based POF has initial, intermediate, and advanced agroforestry trajectory. Farmer's decision to hold back on initial, intermediate, or advanced agroforestry is greatly influenced by its objectives. Thus, the structure of the homegarden depended on the owner's management objectives as has been reported by several previous workers too (Mendez et al., 2001; Kumar and Nair, 2004). This difference suggests that the structural pattern of the vegetation in the home gardens was strongly influenced by the specific needs and preferences of the owners (Abdoellah et al., 2006). POF farmers who want to produce the land for food production through out the management thus developed model namely initial agroforestry by arranging trees number and shade intensity.

POF for all food production through out the management developed in lowland zone of Kulonprogo district through potential cash crop cultivation that are corn, beans, soy, scallions, chili and some other vegetables. While in the middle plain and upper zone cash crops developed are limited on peanuts, maize, cassava, herbs and type of forage fodder. This POF to produce food sustainability is not only in Kulonprogo district but also in general in other locations, especially in home garden system. In both Java and Kerala, homegardening has been a way of life for centuries and is still critical to the local subsistence economy and food security (Kumar and Nair, 2004).

Silvicultural practices developed under POF management were more likely to natural approach starting from the regeneration system and maintenance measures. Silvicultural systems that developed in POF management have traditional impression which is characterized by its random practices; spatial arrangements without considering resources sharing or based on the number of trees in a management unit owned by farmers. Stand characteristic in community forestry is very specific that is having high density with low performance growth. The number of trees resulted is many but the size is small. Trees by trees management does not apply intensive silviculture through thinning, pruning, pollarding, and input giving. In general, the cropping systems in community management use agroforestry (Suryanto et al., 2012b). Traditional agroforestry management, with less intensively managed systems using native trees with perennial crops as an understory, and minimal external inputs, enhances conservation and sustainable use of biodiversity resources (Nobel andDirzo 1997).

Nevertheless POF has the advantage of having a high species diversity and conservation function in life. Homegardens have been described as traditional agroforestry systems that are ecologically and socially sustainable. The concept of social sustainability has two dimensions: positive role to present livelihood conditions and ability to respond to socioeconomic changes (Wiersum, 2006). The trade off between high species-diversity and low 'export' of harvested products from these systems is the main rationale for this belief. Based on this conviction, it is argued that structurally and functionally these multistrata systems are the closest mimics of natural forests yet attained (Lefroy et al., 1999).

In general, POF management in Kulonprogo District has a tendency to keep moving to be more oriented to increase production. This is evident from the space dynamic development which is more intensive to manage agroforestry based on food production and timber with short rotation. Species complexity in agroforestry is therefore not a natural phenomenon, but a result of deliberate attempts and meticulous selection and management by farmers to provide the products they consider are important for their subsistence and livelihood (Nair, 2006). There is a well-known complementarily between direct sales of agroforestry products and self-consumption by the garden owner, which leads to significant savings in the households' day-to-day expenses (Torquebiau and Penot, 2006).

Local knowledge in POF in lowland area is likely based on economical values consid- 
eration while in the middle and upper zones is based on site consition and the developing culture. Traditional agroforestry are complex systems resulted from long history of interactions between local human cultures and the surrounding environments. Landscapes, management systems and techniques conform unique combinations of biocultural heritage of local peoples. Traditional agroforestry systems result from long history of interactions between humans and both natural and agricultural systems and are reservoirs of high biocultural diversity (Altieri, 2001). The structure of POF, however, varies from place to place according to the local physical environment, ecological characteristics, and socioeconomic and cultural factors (Abdoellah, 1990; Karyono, 1990; Ceccolini, 2002; Kumar and Nair, 2004).

Local knowledge in POF management has the tendency to production increase both in initial and intermediate agroforestry as well as in the advanced agroforestries. This tendency is evident in the middle and upper zone with its development towards market orientation. This is shown by the change from multi type sistem to monoculture based on fast growing types and short harvest rotation. Abdoellah et al. (2006) describe a case study of such a transformation in a West Java village in Indonesia, where some villagers, attracted by economic possibilities, have transformed their homegardens in such a way that they have become dominated by few plant species or are approaching even monocultures; the dominant species are cash crops such as vegetables that are in high demand in nearby urban markets.

Meanwhile inthe low land zone continues to develop POF system swith moreintensivein using high external input and high commercial types for the seasonal crop. Rapid development of Indonesia's agricultural sector in response to market pressures, homegardens and other traditional forms of agriculture are increasingly being transformed into income-generating enterprises through the introduction of cash crops (Abdoellah et al., 2006). Commercialization of homegardens by focusing on cash crops has resulted in only short-term improvements in farmers' incomes. It is, however, not certain whether the high initial levels of productivity can be sustained. Cash crops also require high-energy inputs in the form of fertilizers and pesticides (Abdoellah, 1990; Abdoellah et al., 2001).

POF Management in Kulonprogo District actually is an epitome of sustainable natural resource management. Agroforestry systems are regarded as the "epitomes of sustainability' throughout the tropics (Torquebiau, 1992). Tropical homegardens, one of the oldest forms of managed land-use systems, are considered to be an epitome of sustainability (Kumar and Nair, 2004).

However, over time, a strong urge to increase productivity developed POF management. This demand gives management shift of balancing ecological and economic aspects changed to tend to be economy oriented. This, in turn, is determined by the degree to which these functions match with actors' plant-related needs and priorities (Gausset, 2004).

If this shift continues to grow without being followed by an attempt to provide solutions for production increase, POF role as the epitome of sustainable will decrease an done day may end at such a critical condition of forest management. On the basis of these considerations it is necessary to conduct innovative POF management through the construction of adaptive silviculture a san integral part of a productive and sustainable POF. Adaptive silviculture in POF management (AS POF) has two models. The firstmodel of the ASPOF_1 to initial agroforestry based POF management which is productive throughout the management with space arrangement silviculture (intensive pruning and pollarding, commercial thinning and based on needs harvesting) as well as resources sharing (root pruning and enrichment planting with nurse trees types).

In this case, pruning would contribute to the maintenance or the argumentation of the system productivity. Pruning has tradition- 
ally been carried out to obtain fuelwood, but also because it was thought to improve crop production and crop mass, probably because opening the canopy implies that the tree receives more solar radiation, what would be supposed to improve flowering and therefore crop production.

Pruning will not only determine the quantity of sunlight reaching the crop or pasture, but may also ensure good quality timber (Smith et al., 2012). By pruning trees in an agroforestry system, in addition to its effect on wood quality, there may be a benefit to the crops and pasture, due to an increase in the photosynthetic active radiation transmittance (Saptoroand Ernawati 2011) and reduction in the water use by the tree component (Jackson et al., 2000). A market survey indicated that local timber traders and wood processors were willing to pay a premium for quality timber (Bertomeu, 2008).

AS POF_1 keeps agroforestry being able to continually produce food and its derivatives through out the management. Food production either directly (producing edible fruits, nuts, grain, rhizomes and tubers, leaves, flowers etc.) or indirectly (facilitating enhanced and/or sustained production) is a basic function of tropical agroforestry. Crop production in the agroforestry system has better result quality compared to monoculture. Corn physiological responses on chlorophylland relative water content show shigher values compared to inter mediate and advanced agroforestries. This is also followed by higher yield viewed from the canopy, root, 100 seeds weigh tand seed yield dry weight. But for the protein contentin intermediate agro forestry has the highest value, and then followed by the initial agro forestry and advanced agroforestries (Suryanto et al., 2012b).

The second model, AS POF_2 for POFmanagement based on productive intermediate and advanced agroforestries with multilayer production approach through intensive enrichment planting (fast and slow growing, fruit, multipurpose trees and herbal potential). By selecting suitable trees and appro- priate tree management, high quality timber can be produced without influencing agricultural crops excessively (Nerlich et al., 2012). Besides it is also combined in inter unit compatible land management owned by farmers. Potential agroforestry species need to meet context-specific criteria simultaneously regarding ecological, economic, and socio cultural sustainability. Although the need for assessing agroforestry species from an integrated perspective has been recognized (Jose, 2011). Based on these considerations then revitalization management of agroforestry homegarden-dry field is made by integrating in a single management unit (Suryanto et al., 2012a).

AS POF_2 productivity uses multi layer production approach so that produced products not only food-based but also its derivatives that are shade-resistant such aspotentialherbal. Agroforestry are recognized repositories of nontimber products such as medicinal and aromatic plants, ornamentals, bamboos, gums, resins, chemical extractives and green leaf manure (Kumar and Nair, 2004).

This POF with multilayer production is also designed in ecology and conservation purposes. Agroforestry systems can provide an environ mentally friendly approach to land management, combining agricultural and forestry practices (Mosquera et al., 2009). The conservation of biodiversity in agroforestry systems is vital given that human-dominated ecosystem is now a major feature of the earth's landscape (Kareive et al., 2007; Bhagwat et al., 2008).

This agroforestry development in POF management aims not only to maintain the production but also the same ecological values as well as providing opportunities for other products such as tourism. Agro forestry in POF and health resorts could also promote ecotourism or 'health tourism'. Promotion of ecotourism to herbal/home gardens and health resorts catering to aromatherapy or herbal therapy will have its spin off in terms of additional income and rural employment. Value-addition and product 
development at local level wherever possible would also increase the earnings of farmers as well as create rural employment to skilled people and reduce migration to cities (Rao and Rao, 2006).

\section{CONCLUSION}

POF management Kulonprogo District based on agro forestry both in home garden and dry field with amodel ofthe spaceutilization is divided in tothreestrata initial, intermediate, and advanced agroforestries. In the low land zoneis characterized by initial agro forestry practice sbased on food production. Whilein the middle and upper zone, intermediate and advanced agroforestries are more likely to be applied for timber production and under shade type with low economic value but high species diversity. Traditional silviculture is developed following shift in orientation to wards monoculture. Based on this consideration this will require adaptive silviculture schemefor POF management (AS POF) that is productive and sustainable. Thereare two models of AS POF, the first model is AS POF_1 for productive initial agroforestry based POF management agroforestry through out the management for food production and and its derivatives with space arrangement silvicuture measures (intensive pruning and pollarding, commercial thinning and need based harvesting) as well as resources sharing (root pruning and enrichment planting with nurse trees types). The second model is AS POF_2 for POF management based on productive intermediate and advanced agroforestries with multi layer production approach through intensive enrichment planting (fastand slow growing, fruit, multi purpose trees, and potential herbal). It is also integrated into the inter unit land compatible management owned by farmers. AS POF_2 productivity uses multilayer production approach so the products produced not only food-based but also its derivative swhich are shade resistant like potential herbal. It also uses on its management using compatible management approach of inter unit lands owned by farmers.

\section{ACKNOWLEDGEMENT}

The author would like to thank profusely to the Directorate General of Higher Education (DIKTI) of the Ministry of Educationand Culture, Indonesia through research funding provided to the Universitas Gadjah Mada in post graduate grant schemefor the year 2011-2012.

\section{BIBLIOGRAPHY}

Abdoellah O.S., Hadikusumah H.Y., Takeuchi K., Okubo S. and Parikesit. 2006. Commercialization of homegardens in an Indonesian village: vegetation composition and functional changes. Dalam Tropical homegardens: A time-tested example of sustainable agroforestry. Editor Kumar B.M. and Nair P.K.R. Springer Science, Dordrecht.

Takeuchi K., Parikesit, Gunawan B. and Hadikusumah H.Y. 2001. Structure and function of homegarden: revisited. Proceedings of First Seminar of JSPS-DGHE Core University Program in Applied Biosciences "Toward harmonisation between development and environmental conservation in biological production" (21-23 February 2001), pp 167-185. University of Tokyo, Tokyo.

1990. Homegardens in Java and their future development. Dalam Tropical home gardens. Editor Landauer K. and Brazil M.United Nations University Press, Tokyo.

Altieri, M. 2001.Traditional agriculture. Dalam Encyclopedia of biodiversity. Editor Ascher S Academic Press, London.

Barrios,G. L. 2003. Plant-plant interactions in tropical agriculture.DalamTropical Agroecosystems. Editor J. Vandermeer. New York, NY: CRC Press.

Bhagwat SA, Willis KJ, Birks HJB and Whittaker RJ. 2008. Agroforestry: 
a refuge for tropical biodiversity? Trends Ecol Evol 23(5):261-265.

Bertomeu, M. 2008. Can smallholder tree farmers help revive the timber industry in deforested tropical countries? Acasestudy from southern Philippines. Dalam Smallholder tree growing for rural development and environmental services: lessons from Asia. Editor Snelder DJ and Lasco RD. Springer, The Netherlands.

CDPB (City's Development Planning Board) Kulon Progo. 2011. Kulon Progo District Data Bases 2010.

Ceccolini, L. 2002. The homegardens of Soqotra islands, Yemen: an example of agroforestry approach to multiple land use in an isolated location. Agroforest Syst 56: 107-115.

Food and Agricultural Organization (FAO). 2007. State of the World's Forest. FAO Rome, Italy.

Gausset. Q. 2004. Ranking local tree needs and priorities through an interdisciplinary action research approach. J Transdiscipl Environ Stud 3(1):1-17.

IPCC (Intergovernmental Panel on Climate Change). 2007. Climate Change 2007; Mitigation, Contribution of Working Group III to the Fourth Assessment Report of the Intergovernmental Panel on Climate Change. Editor B. Metz, O. R. Davidson, P. R. Bosch, R. Dave, and L. A. Meyer.Cambridge University Press, Cambridge, USA, United Kingdom and New York, NY. 2000. Land-use, Land-use Change and Forestry. Editor R. T. Watson, I. R. Noble, B. Bolin, N. H. Ravindranath, D. J. Verardo, and D. J. Dokken. Special report. Cambridge, Cambridge University Press.

Jackson NA, Wallace JS, and Ong, C.K. 2000. Tree pruning as a means of controlling water use in an agroforestry system in
Kenya. For Ecol Manage 126:133-148. doi:10.1016/S0378-1127(99)00096-1.

Jose, S. 2011. Managing native and non-native plants in agroforestry systems. Agrofor Syst 83:101-105

Karyono. 1990. Home gardens in Java: their structure and function. Dalam Tropical home gardens. Editor Landauer K. and Brazil M. United Nations University Press, Tokyo.

Kareive P, Watts S, Mcdonald R and Boucher T. 2007. Domesticated nature: shaping landscapes and ecosystems for human welfare. Science 316:1866-1869.

Kumar B.M. and Nair P.K.R. 2004. The enigma of tropical homegardens. Agroforest Syst 61: 135-152.

Lefroy EC, Hobbs RJ, O'Connor MH and Pate JS. 1999. Agriculture as a Mimic of Natural Ecosystems. Kluwer, Dordrecht, The Netherlands, 438 pp.

Mendez V.E., Lok R. and Sommarriba E. 2001. Interdisciplinary analysis of homegardens in Nicaragua: micro-zonation, plant use and socioeconomic importance. Agroforest Syst 51: 85-96.

Mindawati, N., Widiarti, A. and Rustaman, B. 2006. Review of Privately Owned Forest Research. Research and Development Ministry of Forestry, Indonesia, Bogor.

MoF (Ministry of Forestry). 2009. Indonesia Forestry Statictic 2009, Ministry of Forestry, Indonesia. Jakarta. 2006. Potential of Privately Owned Forest in Indonesia. Directorate General of Land Rehabilitation and Social Forestry, Ministry of Forestry, Indonesia, Jakarta.

Mosquera-Losada MR, McAdam JH, Romero-Franco R,Santiago-Freijanes JJ, and Rigueiro-Rodríguez A .2009. Definitions and components of agroforestry practices in Europe. 
Dalam Agroforestry in Europe: current status and future prospects. Editor Rigueiro-Rodríguez A, McAdam J, and Mosquera-Losado M. Springer Science. Business Media B.V., Dordrecht.

Nair, P.K.R. 2006. Whither homegardens?. Dalam Tropical homegardens: A timetested example of sustainable agroforestry. Editor Kumar B.M. and Nair P.K.R. Springer Science, Dordrecht.

.1993. AnIntroduction to Agroforestry. Dordrecht, the Netherlands: Kluwer Academi Publishers.

Nerlich, K., Ho"nninger, S.G., and Claupein, W. 2012. Agroforestry in Europe: a review of the disappearance of traditional systems and development of modern agroforestry practices, with emphasis on experiences in Germany. Agroforest Syst DOI 10.1007/s10457-012-9560-2.

Noble I.R and Dirzo R. 1997.Forests as human-dominated ecosystems. Science 277: 522-525.

Nyland, R. D. 2004. Silviculture, Concepts and Applications. The McGraw-Hill Companies, Inc. New York.

Raintree, J.B. 1986. An Introduction to Agroforestry Diagnosis and Design. ICRAF. Nairobi, Kenya.

Rao, M.R., and Rao., B.R. 2006. Medical plants in tropical homegardens. Dalam Tropical homegardens: A time-tested example of sustainable agroforestry. Editor Kumar B.M. and Nair P.K.R. Springer Science, Dordrecht.

Saptoro, M., and Ernawati, N.C.C. 2011. Growth and yield of cassava in agro forestry system using crown tree management: crown pruning for optimization light interception. Agrivita 33:22-31.

Smith J, Pearce BD, and Wolfe MS. 2012. A European perspective for developing modern multifunctional agroforestry systems for sustainable intensification. Renew Agric Food Syst. doi:10.1017/S1742170511000597.

Suryanto, P., Zaki, M. H., Azmy, M., and Azani, M. A. 2011.Silviculture Agroforestry Regime: Compatible management in Southern GunungMerapi National Park, Java, Indonesia. International Journal of Biology, 3(2), 115-126. http://dx.doi. org/10.5539/ijb.v3n2p115

.Widyastuti, SM., Saptohadi, J., Awang, S,A., and Budi. 2012a. Traditional Knowledge of Homegarden-Dry field Agroforestry as a tool for revitalization management of smallholder land use in Kulon Progo, Java, Indonesia. International Journal of Biology. 4 (2), 173-183.

. Putra, E.T.S., Suwignyo, B., and Prianto, S.D.A. 2012b. Silviculture Agroforestry Regime in Community Forestry: Enhancing Compatible Traditional, Intensive, Productive and Sustainable Management. International Conference Forest for People, Tryol, Albach,Austria.22-25 May 2012.

Torquebiau and Penot. E. 2006. Ecology versus economics in tropical multistrata agroforests. Dalam Tropical homegardens: A time-tested example of sustainable agroforestry. Editor Kumar B.M. and Nair P.K.R. Springer Science, Dordrecht.

1992. Are tropical homegardens sustainable? Agric Ecosyst Environ 41: 189-207.

Wiersum K.F. 2006. Diversity and change in homegardencultivation in Indonesia. Dalam Tropical homegardens: A time-tested example of sustainable agroforestry. Editor Kumar B.M. and Nair P.K.R. Springer Science, Dordrecht. 